\title{
An Explanation for the Growing Institutional Capacity of the Arctic Council
}

\author{
Andrew Chater \\ Brescia University College
}

\begin{abstract}
In 1996 the Arctic states-Canada, Denmark, Finland, Iceland, Norway, Sweden, Russia and the United States-created the Arctic Council as an institutionally weak body. It lacked bureaucracy to provide direction for the institution or a stable budget. The council had weak institutional capacity. In $201 \mathrm{I}$, the council announced the creation of a permanent secretariat. In 2014, it announced the creation of a "project support instrument," which is similar to a budget. Why did states support increasing the institutional capacity of the Arctic Council? The Arctic Council's institutional capacity is growing because all states perceive that this is in their interest as it helps the institution carry out its expanded mandate; however, states have increased capacity in such a way as to ensure the council will not become overly powerful. In addition, effective negotiation tactics by the Nordic governments made the expansion of the council's institutional capacity more likely. Most current literature explains that the council has weak institutional capacity and its expansion has been a natural evolution. This work contributes that the council's expansion has been a political process, resulting from tactful political manoeuvre and negotiation. The method utilized is historical process tracing, drawing on council documents and interviews with key council decision-makers. Scholars who seek a stronger and more activist Arctic Council should consider its continued weakness.
\end{abstract}

The Northern Review 48 (2018): 51-80 
In 1996 the Arctic Council lacked a permanent secretariat to perform bureaucratic functions, and a stable budget to achieve objectives. Today, its institutional capacity is expanding. As the premier international institution in the Circumpolar North, the Arctic Council's capacity affects the ability of all state policy-makers to achieve their desired outcomes in the institution. Lack of a secretariat, for example, makes coordination of information between council working groups more difficult, which hinders efforts by states that want a harmonized council agenda since a secretariat could subvert the will of a given state for a more flexible council agenda.

Institutional capacity refers to "the ability [of institutions] to perform functions, solve problems and set and achieve objectives." ${ }^{1}$ For the purposes of this article, an institution has strong institutional capacity if its bureaucracy is able to provide direction and carry out projects without state approval - that is, the institution itself can perform functions, solve problems, and set its own objectives. An institution has weak institutional capacity if it cannot take any action without state approval, or if the institution is merely an extension of a group of states - that is, the institution itself is unable to perform any functions without state action. This idea is not to say that strong institutional capacity is necessarily desirable; weak capacity could serve the purpose of a particular institution.

In 1996, the Arctic Council had weak institutional capacity because states did not create a permanent secretariat; its future ability to carry out functions, solve problems, or achieve objectives would depend on state willingness to support the council, which ebb and flow as government priorities shift. In 2011 the Arctic Council announced that it would establish a permanent secretariat in Tromsø, Norway. Apart from that, in 2014 member states also established a "project support instrument," which is similar in many ways to a stable budget.

This article answers the following question: why did states support increasing the institutional capacity of the Arctic Council? The Arctic Council is the region's most prominent international institution, made up of all eight Arctic states as members-Canada, Denmark, Finland, Iceland, Norway, Russia, Sweden, and the United States-and with the major Indigenous peoples' organizations as permanent participants. The council carries out projects on environmental protection and sustainable development by consensus. Examples of projects include environmental 
assessments and emergency response simulations. Typically, state scientists carry out research and issue policy recommendations, with bi-annual plenary meetings to review progress. On occasion, the council has served as a venue to negotiate an international agreement. Current literature has noted that expansion of institutional capacity has taken place, but this article explains the interests behind this change. Initially, Nordic policymakers argued that the council was an institution worthy of a stable budget and strong bureaucracy. Many officials from Canada, Russia, and the United States did not share this view. The debate shifted as the Nordic governments argued for the necessity of a targeted Arctic Council trust fund and demonstrated the utility of a permanent secretariat in the face of a growing workload. The central argument is that the Arctic Council's institutional capacity is growing because all states perceive that this is in their interest as it helps the institution carry out its expanded mandate; however, states have increased capacity in such a way as to ensure the council will not become overly powerful. In addition, the expansion of the council's institutional capacity may not have occurred had it not been for effective negotiation tactics by the Nordic governments, which collectively showed that a secretariat would enhance the institution. Overall, the negotiation process that led to the secretariat shaped the evolution of the council and its capacity.

This article contributes to literature giving competing ideas about the Arctic Council's institutional capacity. Most research examining the council characterizes it as an institution with a weak bureaucratic structure, as exemplified by the writings of political scientists Oran Young, ${ }^{2}$ Rob Huebert, $^{3}$ Timo Koivurova ${ }^{4}$, and Olav Schram Stokke, ${ }^{5}$ as well as American diplomat Evan Bloom ${ }^{6}$ and consultant Terry Fenge. ${ }^{7}$ More recent work by international law researcher Belen Sanchez Ramos argues that the council's institutional capacity is expanding "to face the rapidly changing circumstances in the Arctic that have increased the challenges and opportunities in both volume and complexity," echoing reasons for the establishment of the permanent secretariat given by the council itself. ${ }^{8}$ Ramos argues that "the creation of an international organization is the best way to improve the global governance of the Arctic." This research begs a question as to what prompted this change. Positivist theories, such as functionalism, assume that states will let international institutions evolve organically to help them operate more efficiently. ${ }^{10}$ Neo-liberal 
institutionalism, in contrast, argues that states expand the capacity of an institution to help it achieve absolute gains, tempered by norms, path dependence, and the negotiation tactics of states. ${ }^{11}$ The work reported on this article shows that the negotiation process that led to the secretariat has shaped evolution of the council and its capacity, adding to Ramos's explanation for the emergence of a new form of Arctic governance. The council did not exactly evolve automatically, as per functionalism; its evolution was a political process, more in line with neo-liberal institutionalism.

This research informs debate about the role of the council. A body of work advocates that the council do more than it currently does. The implementation of the recommendations of these authors will require a larger council bureaucracy than currently exists. ${ }^{12}$ For example, some work advocates that the council create more formal policies and treaties, which require bureaucracy for enforcement and implementation. ${ }^{13}$ Some work assumes the council is powerful enough to take action independent of states, such as new regulations to protect the environment or the creation of a new agreement. ${ }^{14}$ This article shows that the types of council reforms authors advocate are not likely in the absence of state initiative, given the institutional power of the council.

This article employs historical process-tracing to analyze the history of the council's institutional capacity. I examined more than 5,000 pages of council documents, such as memos, communiques, agendas, participant lists, and meeting minutes. I assembled a timeline of the council's institutional capacity, paying special attention to instances of debate and change. The documents I used are available on the council's website. However, these documents are invariably imperfect, since state delegates and policymakers can edit them through a standard approval process. They also do not provide an explanation as to why the council undertook certain action. So, throughout 2013 , I completed thirty-three semi-structured interviews with people who worked for the council and made the key decisions in question. The interviews took place in person, via email, or via Skype. I then added their empirical insights to the timeline. These were elite interviews with trustworthy subjects; yet, qualitative interviews are invariably subject to lapses in memory and differences in interpretation. Beyond interviews, in October 2013 I attended a meeting of the Arctic Council in Whitehorse, Yukon, where I was able to witness the council's institutional capacity up 
close and see debates about expanding the institution. News articles and other secondary sources contributed information to the timeline, as well.

\section{The Evolution of the Arctic Council's Institutional Capacity}

There have been three eras in the debate over the institutional capacity of the Arctic Council. From 1991 until 1998, states created the council and debated whether the institution should have a secretariat and stable budget. From 1998 until 2007, states continued to debate the merits of a permanent secretariat and stable budget, though the discussion began to shift towards discussion of project support mechanisms. From 2007 until the present, states have actively supported increasing the institutional capacity of the council, largely due to actions by the Nordic countries. In general, Denmark, Finland, Iceland, Norway, and Sweden have urged the council to develop strong institutional capacity, which Canada, Russia, and the United States have resisted to varying extents.

1991-1998

From 1991 until 1998, states debated whether the council should have a stable budget and a permanent secretariat. This section addresses four key questions. First, how did the question of the council's institutional capacity emerge? Second, what were the major debates regarding the council's institutional capacity? Third, what were the positions of the various actors prior to the creation of the council regarding its institutional capacity? Fourth, why did the preferences of some actors prevail over others and who exerted the most influence?

First, the question of the council's institutional capacity emerged because of the informal nature of the Arctic Environmental Protection Strategy (AEPS), the pre-cursor to the Arctic Council. When creating any new institution, questions of its powers quickly arise. The story of the Arctic Council is a complex and multi-faceted series of events. In streamlined summary, momentum for creating the Arctic Council started in the 1980s as states became interested in improving relations with the Soviet Union and addressing pollution in the Russian Arctic. An interviewee illustrated that states knew there was extensive pollution in the Soviet Arctic, but the extent of that pollution was relatively unknown. ${ }^{15}$ Finland organized negotiations to create the AEPS, which came into being in $1991 .^{16}$ The AEPS was a strategy, rather than an institution or an organization, and it 
did not have a permanent secretariat. Rather, states set priorities at annual meetings, and four working groups staffed by government scientists and researchers completed the work between meetings. It was a strategy for information synthesis and sharing. Through the work of the AEPS, by 1995 states and Indigenous peoples' organizations learned that there was extensive pollution due to unsafe storage of polychlorinated biphenyls (PCBs) in the Russian Arctic, some 180,000 tonnes produced during the Cold War. ${ }^{17}$ There was also increasing pressure to expand the work of the AEPS to address human issues, particularly from Canada seeking to expand the strategy's work to include work more relevant to North America, as well as the Indigenous peoples' organizations that sought a greater role in Arctic governance. ${ }^{18}$ In particular, the well-being of Russian Indigenous peoples declined during the 1990s and Indigenous peoples' organizations wanted action. ${ }^{19}$ An interviewee from the United States said that the seven other Arctic states wanted to ensure that Russia would be accountable amid reports of corruption following the collapse of the Soviet Union. ${ }^{20}$ States naturally had to address whether the council would have bureaucratic powers similar to the AEPS, or whether the creation of an institution, as opposed to a "strategy," warranted new bureaucratic arrangements.

In regards to the second question, the main debate over the council's policy-making role concerned whether the new institution would have a stable budget and permanent secretariat. The government of Canada discussed the creation of the Arctic Council in a meeting with the United States administration in February 1995, adopting a proposal for an international Arctic organization promoted by think tanks, academics, and Indigenous peoples' organizations for a decade. ${ }^{21}$ After informal negotiations throughout 1995, policy-makers from the other Arctic states agreed that an institution would be beneficial and formal negotiations took place in 1996.22 At the third major round of negotiations in June 1996, states finalized-after compromise by the United States and Russia-a proposal championed by Canada and the Nordic states that the Arctic Council would have a broader mandate than the AEPS by including sustainable development. ${ }^{23}$ The question of the bureaucratic mechanism necessary for this institution emerged as the new body would have a larger, more complex job than the AEPS. 
As to the third question, two alignments emerged during the negotiations in June, each with different positions about the necessary institutional capacity of the council. Canada, the United States, and Russia resisted creating a council with a stable budget and secretariat. In contrast, the Nordic states argued that the institution should have a permanent secretariat and stable budget. The permanent participants were amenable to a permanent secretariat and budget, although their main concern was securing their own participation in the council. Canadian policy-makers were leery of a permanent secretariat and budget on the grounds that these measures would make the council Europe-centric. Multiple interviewees recounted that, by virtue of their numbers, the Nordic countries would provide most of the budget for the council and secretariat, which, according to Canadian officials, would ensure the council focused on European projects. ${ }^{24}$ The alternative would be for Canada or the United States to provide the bulk of the council's budget, which would create financial burden. Canada did not necessarily oppose a secretariat altogether; in 1990, in negotiations to create what would become the AEPS, Canada had offered to host a secretariat. ${ }^{25}$

Meanwhile, United States and Russian policy-makers opposed a permanent secretariat and budget because they sought a weak organization that would rely on voluntary contributions from states. United States and Russian policy-makers feared that a strong council would challenge their autonomy to act in the Arctic region. ${ }^{26}$ An interviewee recounted that in the summer 1996 negotiations, United States policy-makers led the charge against the secretariat and stable budget by arguing that a strong council would inappropriately act as a "regional voice."27 Additionally, interviewees said that United States policy-makers were leery that, as a great power, the United States would be called on to provide most of the council funding. ${ }^{28}$ Policy-makers were aware that a permanent secretariat with a stable budget could challenge state autonomy. ${ }^{29}$ As one Canadian policymaker stated, "permanent secretariats become their own gods." 30 Canada likely would have compromised on this issue if the Nordic countries presented a proposal to address Canada's concerns, which was not true of the United States and Russia. These two countries would not tolerate strong bureaucratic elements. Two alignments emerged in negotiations, 
with Canada, the United States, and Russia fairly united in opposition to a permanent secretariat and budget, for different though complimentary reasons.

The Nordic countries wanted a permanent secretariat and budget for two reasons. First, they argued that these would make the council a more legitimate institution. An interviewee offered that the Nordic countries are used to organizations with strong bureaucratic elements. ${ }^{31}$ Some policymakers believe the Nordic preference for strong bureaucracies is cultural. ${ }^{32}$ In the later 2000s, an interview subject discussed that Norway and Iceland supported a secretariat as both wanted to host the organization to increase their legitimacy as an Arctic power. ${ }^{33}$ Second, policy-makers were keenly aware that there was a strategic interest in a strong council bureaucracy for the Nordic countries. Such institutions could help keep Russia accountable in addressing environmental issues - as an interviewee said, there was a fear among policy-makers that corruption in Russia would thwart efforts to protect the environment. ${ }^{34}$ The secretariat could serve as a body to monitor the implementation of policy and funds in Russia, which would thus ensure that Russia lived up to its international obligations. Though there were differences of opinion, interviewees recounted that, overall, Nordic states favoured the creation of a strong Arctic Council institution and so favoured the creation of a strong council bureaucracy. ${ }^{35}$

As to the fourth question, the preferences of Canada, Russia, and the United States prevailed over the preferences of the Nordic states because the governments of the United States and Russia would not compromise. Canada could be persuaded, but the United States and Russian policymakers would simply not accept a council with a strong bureaucracy and budget. The Nordic governments were more willing to compromise to ensure the creation of a council, which was seen (according to an interviewee) as a key tool to ensure co-operation with Russia. During the beginnings of the council, the understanding emerged that host countries would provide secretariat services and organize meetings. ${ }^{36}$

In summary, the question of the appropriate institutional capacity of the council emerged naturally as state delegations discussed whether to create a new institution. A major question was whether the council should have a permanent secretariat and stable budget, or whether the council should adopt the more flexible approach seen in the AEPS. The Nordic countries favoured a strong council and thus a strong institutional capacity, 
while Canada, Russia, and the United States saw that a Europe-centric institution could threaten state autonomy. Ultimately, the position of Canada, Russia, and the United States prevailed, as Russia and the United States were unwilling to compromise. The Nordic countries did not provide compelling evidence that a secretariat was necessary.

1998-2007

From 1998 until 2007, the Nordic countries unsuccessfully pressed for a secretariat and states debated the merits of establishing systemized financial support for the council. This section answers three key questions. First, what were key debates regarding the council's institutional capacity? Second, what were the positions of the various actors? Third, why did the preferences of some actors prevail over others and who exerted the most influence?

In regards to the first question, the first major debate in this era was whether the council should have a permanent secretariat. The council rules of procedure, finalized in 1998 negotiations, establish that "an Arctic state may volunteer to provide secretariat functions" for any working group. ${ }^{37} \mathrm{In}$ addition, the permanent participants would have a permanent secretariat, as the secretariat created in 1993 by Denmark to aid Indigenous participation in the Arctic Environmental Protection Strategy would continue. ${ }^{38}$ The "host country" or chair of each council term was to provide "secretariat functions." ${ }^{39}$ Denmark provided the bulk of Indigenous Peoples Secretariat (IPS) funding, about US $\$ 110,000$ a year, ${ }^{40}$ with additional support from Canada and Norway. ${ }^{41}$ The United States Department of Oceans Affairs provided secretariat functions for the council from 1998 until 2000. ${ }^{42}$ Iceland hosted the Conservation of Arctic Flora and Fauna working group as well as the Protection of the Arctic Marine Environment working group, while Norway hosted the Arctic Monitoring and Assessment Programme (and the Arctic Contaminants Action Program, or ACAP). Canada hosted the Sustainable Development Working Group as well as the Emergency Prevention, Preparedness, and Response working group. ${ }^{43}$ Finland, Russia, and Sweden did not host any secretariats. In 2000, the United States began hosting a temporary secretariat to facilitate the creation of the Arctic Climate Impact Assessment. ${ }^{44}$ Each secretariat had between two and six employees. The question lingered as to whether this arrangement would be workable. 
In 1999, Nordic countries wanted the council to institute a stable budget and a permanent secretariat to improve the functionality of the council. Their views had not changed since the negotiations to found the council. Norway first raised the issue and made a statement advocating a permanent secretariat at the May 1999 council meeting in Anchorage, Alaska. At this meeting, in discussions concerning the council's secretariat functions, Denmark's delegation raised the point that the country gave the IPS US $\$ 110,000$ in 1999 and that other states should contribute greater funds. ${ }^{45}$ In response, the Canadian delegation suggested that the Indigenous peoples' secretariat "pursue funding sources from the private sector." ${ }^{6}$ The delegation from Norway then "reiterated its belief that the council needs a common budget and that the members should share all the costs." ${ }^{77}$ The United States' objection to such capacity had not changed and its delegation then vetoed further discussion of a permanent secretariat or stable funding as it immediately "repeated its position that it could not support mandatory funding for the secretariat or make the council a formal 'international organization' but that it was currently trying to solicit funds from the private sector," such as the MacArthur Foundation. ${ }^{48}$ Other delegations did not state their views. ${ }^{49}$

Discussion continued at two other council meetings. First, at the October 2000 Ministerial Meeting in Barrow, Alaska, the Norwegian delegation again argued "the need for a permanent secretariat." ${ }^{50}$ It called for a "more balanced sharing of financial responsibility for the working group secretariats." ${ }^{51}$ It also indicated that states should discuss the council's structure. ${ }^{52}$ Other states did not address the Norwegian statement. States drafted and released a statement at the close of this meeting to restate their support for the council. The resulting Barrow Declaration did not indicate interest in a secretariat but stated "strong support for achieving reliable funding for all Arctic Council activities." ${ }^{3} 3$ Second, further discussion of the structure of the Arctic Council occurred in June 2001 at the council meeting in Rovaniemi, Finland, during an agenda item reviewing the council's administration. To open these discussions, the Danish delegation indicated its support for a permanent secretariat. ${ }^{54}$ Delegations from Norway and Sweden echoed Denmark's support for a permanent secretariat, along with "more standing financial arrangements." 55 Before other states could state their opinions, the United States and Russia both opposed such "drastic changes" in the council, vetoing a permanent secretariat or 
standing monetary contributions. ${ }^{56}$ The United States and Russia next indicated some willingness to entertain changes in the composition of the working groups, a small concession in response to the calls for a permanent secretariat and stable funding. ${ }^{57}$ Nordic delegations advocated that the council needed greater institutional capacity, which the United States and Russia resisted.

A problem with Nordic lobbying for greater institutional capacity is that they failed to demonstrate why a secretariat and stable budget were necessary. The statements above suggest these countries sought institutional capacity for its own sake. This problem reversed in 2001, after Finland became council chair. Its government commissioned an independent consultant report that advocated states expand council institutional capacity. It recommended a re-organization of council working groups and identified that a permanent secretariat and stable funding could solve longterm problems of institutional memory, capacity to fulfill instructions, and outreach/communication. ${ }^{58}$ States responded that they recognized "the need to reinforce efforts to finance circumpolar co-operation due to Russia and the United States' clear opposition to discussing the structure of the council" in the 2001 Inari Declaration. ${ }^{59}$

The debate changed in 2003 as the Nordic countries abandoned the lobbying of states for a secretariat and stable budget and a second debate emerged over a new idea, a "project support instrument," to increase the institutional capacity of the council. In early 2003, ahead of the April council meeting in Reykjavik, policy-makers from the chair country, Iceland, sought to develop new proposals to improve the institutional capacity of the council. They asked the chairperson of the Nordic Environmental Finance Corporation (NEFCO), Harro Pitkanen, to give a presentation to the council about the potential for the corporation to fund council projects or manage a "trust fund" for council projects. ${ }^{60}$ The presentation occurred in April and state delegations, unsure about the utility of the idea, mutually agreed to hear more about the proposal after the preparation of a detailed proposal. ${ }^{61}$ The NEFCO is an international environmental granting agency consisting of the five Nordic countries. We can view the NEFCO as an extension of Nordic interests and policy rather than as an autonomous body. The next step in the policy-making process occurred in October 2003 at the council meeting in Svartsengi, Iceland. At this meeting, the NEFCO gave a presentation and formally proposed 
that states establish a council trust fund. The NEFCO proposed a simple system in which states would contribute to a NEFCO fund and administer that fund as an "assembly of contributors." 62

The proposal theoretically had the support of the Nordic states, as NEFCO members, but lacked the support of Canada, Russia, and the United States. Immediately following the presentation, the United States expressed opposition to this system, because it would "potentially change the way the Arctic Council was organized as a consensus forum, since not all the member states were likely to become contributors." ${ }^{63}$ Canada echoed this concern and Russia held back its opinions, as a veto had already occurred. ${ }^{64}$ In response, Pitkanen promised more details but rejected the United States' assertion that a trust fund would change the nature of the council. ${ }^{65}$ The NEFCO proposed that it set up an expert group to develop the proposal further, which no state rejected. ${ }^{66}$ The prospect of a trust fund did not look particularly promising.

The policy-making process to construct the trust fund continued in 2004 and 2005. At the May 2004 council meeting, Iceland announced an "ad-hoc expert group" led by Pitkanen and the NEFCO. ${ }^{67}$ Finland, Norway, Sweden, and the United States appointed representatives to the group. ${ }^{68}$ The United States participated, although it opposed changes to the council's structure, which at first glance seems curious. United States policy-makers likely participated to ensure they influenced the process and protected state interests. The group developed the proposal during the summer of 2004, with United States policy-makers warming to a projectoriented fund. It updated the council about its progress at the November 2004 council meeting in Reykjavik, Iceland, and emphasized that the fund would be "action-oriented," "complimentary," and "voluntary." 69 States then mutually agreed to set up a trust fund pilot project specifically to fund Arctic Contaminants Action Program (ACAP) projects. The NEFCO would hold the fund and contributors would allot the fund by consensus. The fund would be a "voluntary, non-exclusive mechanism for financing specific priority projects that have already been approved by the Arctic Council." 70 The council would not use the fund for operating costs, but rather specific projects. ${ }^{71} \mathrm{~A}$ council trust fund appeared in the offing. However, states did not agree on the importance of a trust fund and so the project ran into obstacles. To become operational, states agreed the fund would require 3 million euros. ${ }^{72}$ Three major events took place at the 
April 2005 council meeting in Yakutsk, Russia. ${ }^{73}$ First, delegations from Finland, Norway, Iceland, Sweden, and Russia announced contributions to the fund, though Russia did not specify how much it would contribute. ${ }^{74}$ Second, delegations from Denmark and Canada stated that they would not contribute. ${ }^{75}$ Third, the United States delegation did not offer contributions. The trust fund had trouble obtaining necessary funds and so was not operational by October $2006 .^{76}$

In regards to the second question, as to the positions of various actors between 1998 and 2007, we can see earlier divisions over council institutional capacity reflected in this era. In the first debate, Canada, Russia, and the United States questioned a permanent secretariat and stable budget, leery that these institutions would compromise state autonomy and ensure the council reflected European interests. The Nordic states desired a strong council to hold Russia to account in the Arctic. As to the second debate, Finland, Iceland, Sweden, and Norway strongly supported a council trust fund as a means to accomplish some of the goals of a stable budget. It would provide some stable funding needed to increase the institutional capacity of the council. In addition, it would be a way to hold Russia accountable for environmental issues, as most funding would go to the ACAP projects concerning Russia. The United States was hesitant amid typical concerns over autonomy, sovereignty, and financial burden. The fund could increase the power of the European countries in the council, which seemed eager to contribute to the fund. Canada and Denmark opposed a trust fund in which only contributors could allot funds, fearing a shift in council power dynamics. In order to participate in the trust fund, states would need to provide funds. This change could have impacted power dynamics in the council. All states would have an equal say in the allotment of funds, even though states would give different amounts of money. If a given country could not make a financial contribution for any reason, it would not have a say in a key area of council decision-making. Denmark was also leery about the trust fund's impacts on its Indigenous Peoples' Secretariat support. It already contributed money to the secretariat for Indigenous peoples' organizations and did not want to contribute money to a new body. Denmark opposed the project support instrument even though it was a member of the NEFCO. Russia supported a trust fund if its officials could gear it to fulfill national interest and use it to support projects in Russia. The fund would provide resources for the ACAP projects, which mostly 
focused on Russia. However, it withheld information on its contribution because the Russian government wanted clear guarantees that the funds would support Russian projects. ${ }^{77}$

In regards to the third question, as to which preferences prevailed, the United States proved to be the most important country in the negotiations as its policy-makers blocked efforts to give the council greater institutional capacity. Yet the Nordic countries, except Denmark, also exerted influence. They were able to set up a trust fund pilot project despite resistance from the United States and Canada. Denmark proved less influential, as the trust fund did not reflect its preferences, despite its NEFCO membership. The trust fund was a step toward increasing the capacity of the council.

What about the Indigenous peoples' organizations? These groups had relatively little involvement in discussions of a permanent secretariat and stable budget. They generally supported increasing the capacity of the council, but had to prioritize their involvement in council projects due to lack of funds. These groups simply cannot participate strongly in every council project. Whereas states can send dozens of representatives to plenary, non-working-group meetings of the council, these groups must get by with three or four delegates. Whereas large government bureaucracies support council activities, the staff of Indigenous peoples' organizations is typically part-time. The establishment of a permanent secretariat was not a top priority, whereas stable funding for their own participation and projects important to human development were.

2007-Present

From 2007 onward, the Nordic countries successfully negotiated to increase the institutional capacity of the council. In 2012 and 2013, states opted to create a permanent secretariat to deal with the increasing workload of the council, confident that such an institution could be tailored to suit state interests. In 2014, the council saw the creation of a Project Support Instrument, which is not a stable budget, but resulted from those discussions. This section answers two questions. First, when did the debate around the council's institutional capacity change and what were the positions of the various actors regarding institutional capacity? Second, why did the preferences of some actors prevail over others and who exerted the most influence? 
In regards to the first question, the debate around the council's institutional capacity shifted in 2007 when three Nordic states opted to host a joint secretariat. At the April 2007 council meeting, the delegation from Norway proposed, without much warning, that it would host a "joint secretariat" on behalf of Norway, Denmark, and Sweden for six years. ${ }^{78}$ Denmark and Sweden accepted the proposal. Other member countries were not able to veto this action, as it was not a council decision. The rules of procedure gave the host country the right to organize the secretariat and to establish a joint secretariat. The rules of procedure did not prohibit a joint secretariat and did not specify how states must host the secretariat.

As a result, at the May 2012 deputy ministers' council meeting, Sweden initiated a discussion of the effectiveness of the temporary secretariat and all of the assembled ministers mutually agreed this secretariat could become a permanent one. ${ }^{79}$ Despite earlier opposition to a secretariat, the new institution came together smoothly. The negotiation process took place in 2011 and 2012 outside of council meetings - states did not discuss the matter openly in council meetings. The main disagreement in these negotiations was the location of the secretariat as the governments of both Iceland and Norway sought to host the new body. Interviewees said that in negotiations, policy-makers from the United States and Canada made it known they wanted the secretariat in Iceland since it is about halfway between Europe and North America and thus an appropriate location. ${ }^{80}$ Norway, however, promised to invest more resources in the secretariat. ${ }^{81}$ Russian policy-makers supported Norway's proposal because Norway is closer to Russia than is Iceland. ${ }^{82}$

Ultimately, in early 2012, the government of Norway sent communications to the government of Iceland and convinced the country to withdraw its bid by promising that the chair of the secretariat would be Icelandic. ${ }^{83} \mathrm{~A}$ highly placed interviewee said that there was a strong Russian candidate who many policy-makers believed would make a good chair, but United States officials did not want a Russian in the position, amid lingering distrust between the countries. ${ }^{84}$ The government of Norway wanted to host the secretariat in order to establish Tromsø as the "capital of the Arctic" and a base for companies (as well as researchers) that operate in the Arctic region. ${ }^{85}$ It is already the home to several Arctic institutions, such as the Barents Council. The government of Iceland wanted to host the secretariat because many policy-makers believe its economic future is 
in the Arctic ${ }^{86}$ Icelandic policy-makers believed the secretariat would give Iceland prestige and power. ${ }^{87}$ Iceland wants Reykjavik to be the "Arctic capital." 88 Ultimately, Iceland gave up its bid for the secretariat because it gained an acceptable compromise. ${ }^{89}$ The secretariat became operational in 2013.

Why did states come to accept the utility for a permanent secretariat? Support for a permanent secretariat among most Nordic countries has been consistent, stemming from the preference for the council to be a robust international body. An interviewee confirmed that the reason that policy-makers from Norway, Denmark, and Sweden wanted to create the temporary secretariat was to demonstrate the utility of a more permanent body. ${ }^{90}$ Why did the United States, Canada, and Russia reverse earlier opposition to a permanent secretariat? There were two major reasons. First, interviewees said that United States, Canadian, and Russian policy-makers had experiences in other organizations that led them to realize states could control secretariats and that they could be useful ${ }^{19}$; one example mentioned in interviews was the Antarctic Treaty Secretariat. ${ }^{92}$ International institutions with secretariats existed before the council, and evidence mounted that they were controllable. Some council policy-makers became convinced that a secretariat would benefit the council, as secretariats had been useful in these other contexts. ${ }^{93}$ Second, policy-makers realized the council's work was becoming more complex and had to accept the benefits of a permanent secretariat, based on experience working with the temporary secretariat. A review of semi-annual summative Senior Arctic Official reports to governments (which account for all council projects) reveals the council's workload tripled over the first fifteen years of its existence. Issues such as climate change became present throughout the history of the council and came to occupy a major part of the council's agenda (such as the council's 2004 Arctic Climate Impact Assessment). Earlier projects led to follow-up projects, yet working groups did not stop creating new projects. States and policy-makers entrusted work to the council as it showed that it could complete projects on time (the Arctic Climate Impact Assessment is once again a good example). New states and organizations gained observer status and increased the profile of the institution. A permanent secretariat increased institutional memory and eliminated the "learning curve" that a host country must address. ${ }^{94}$ The council formed a secretariat when the mutual value of such an institution became apparent. 
The debate around the council's institutional capacity further changed when council states began creating the project support instrument (PSI), which came into being in 2014. The PSI changed the debate around institutional capacity because states stopped discussing the need for a stable budget in order to focus on the more informal instrument. Progress to create a trust fund had stalled in 2006 and so states renamed the fund to emphasize that it would not be a tool to fund general council operations. States first began to refer to the fund as the PSI in 2007. The implementation of the PSI proceeded in five rounds of negotiations. Between November 2007 and November 2008, Russia and the Nordic countries, save Denmark, vigorously debated how much money was necessary to create the PSI, how much countries would contribute, how much money would be spent in Russia, and which organization would administer the fund. ${ }^{95}$

Negotiations continued in November 2008 at the council meeting in Kautokeino, Norway. Russia stated it was ready to move forward with the PSI and had terms of reference ready for approval. It would be nearly 3 million euros, administered by NEFCO, focused on Russia with contributions from Russia, Finland, Norway, Iceland, and Sweden. ${ }^{96}$ Meeting minutes record,

The USA questioned that, given that all [Arctic Council] funding is voluntary and that project steering groups are subsidiary to the [working group secretariat] why the PSI committee should be limited only to those who financially contribute, and suggested that no member of the [Arctic Council] should be prevented from participating in the PSI. $^{97}$

The United States delegation stated it would need more time to review the project support instrument (PSI), leery of potential corruption in Russia. In response, all states agreed to postpone approval of the PSI until December, to give the United States time to complete an internal review. ${ }^{98}$

This deadline passed as the PSI hit new roadblocks in Russia. The PSI was not operational because Russia had not finalized "its inter-agency process" 99 to determine how it would administer the funds from the NEFCO within the complex structures of its government. After two years, in November 2011 at the council meeting in Lulea, Sweden, the NEFCO said Russia had completed the inter-agency process. ${ }^{100}$ Russia was to be 
transparent with money provided by the trust fund. The NEFCO would ensure that the money would not be wasted by the Russian government or lost to corruption. With this, after the NEFCO's assurance of Russian accountability, the United States delegation said it would donate US\$1 million by the end of 2011, even though the trust fund would allot funds by consensus. ${ }^{101}$ Its contribution assured it would have involvement in the PSI. The trust fund now had the money it needed to continue.

States' contributions increased and the PSI became operational in 2014, with 16 million euros at its disposal. ${ }^{102}$ The fund is not for any council project. It is for "action-oriented Arctic Council projects focusing on pollution prevention in the Arctic." ${ }^{103}$ Russia is contributing a total of 10 million euros. The remaining contributors are Finland, Iceland, the NEFCO, Norway, the Sámi Parliament, Sweden, and the United States. ${ }^{104}$ According to the NEFCO, "The PSI will be financing project preparation activities, such as project identification and concept development, feasibility studies, environmental impact assessments, business and financing plans, preliminary design, preparation of tender documents, tendering and evaluation." ${ }^{105}$ In addition, "The main focus of the fund is to finance initiatives that can mitigate climate change and reduce releases of hazardous substances." 106 The PSI is similar to a stable budget as it provides money states can rely on to fund projects, regardless of the whims of individual countries. States no longer discuss the notion of creating a stable budget. The PSI came to replace that discussion in the council's debate; indeed, as the previous section indicates, the PSI grew specifically out of efforts from Iceland to develop funding mechanisms as an alternative to a funding instrument.

In regards to the second question, as to which state was the most influential in negotiations, Norway became most influential, as it was a leader in the movement to increase the council's institutional capacity. The United States exerted influence in ensuring that the council is not a more powerful body, and it led the case for a weak secretariat. Interviewees contended that it appears unlikely the secretariat will become extremely powerful because each state only contributes US $\$ 125,000$ annually (except Norway, which contributes more as the host of the secretariat). ${ }^{107}$ Norwegian policy-makers wanted the institution to be more powerful ${ }^{108}$; however, with its small budget, it will not have the ability to hire a large research staff or policy-makers to influence states. Norway found a means 
to reduce the influence of the United States by using the council's terms of reference to create a situation that demonstrated the utility of a permanent secretariat. It also created a tool similar to a stable budget, but which won approval from all states. The fact that a stronger fund or a stable budget did not result from efforts to better fund the council reflects the preferences and interest of the United States. Overall, Norway led the cause to create a permanent secretariat, while the United States had serious reservations.

The administrative work of the council today is split between the chair country and the secretariat. Each member state serves as chair for two years on a rotating basis. The chair of the institution organizes meetings of the Arctic Council, sets rules on delegation sizes, ${ }^{109}$ chairs the actual meeting, ${ }^{110}$ proposes meeting agendas, ${ }^{111}$ releases council documents, ${ }^{112}$ and plays a role in communication. ${ }^{113}$ The chair also provides overall priorities for the institution. The secretariat helps organize the meetings, ${ }^{114}$ facilitates communication between council actors, ${ }^{115}$ maintains council records, ${ }^{116}$ and operates outreach activities for the institution. ${ }^{117}$ It runs the logistics of the institution.

\section{Conclusion}

This article has shown that the institutional capacity of the council is growing as it establishes a permanent secretariat and project support instrument. The Arctic Council's institutional capacity is growing because all states perceive that it is in the interest of all member states, as this capacity helps the council carry out its expanded mandate. However, states are increasing the institutional capacity to ensure that the council will not be an overly powerful actor. The Nordic countries and their political manoeuvring proved to be a key factor, as well.

The council's work is more complex than in the past and the expansion of the institutional capacity is a response. The expansion was not automatic, as per a functionalist hypothesis. Norway and the Nordic countries lobbied for years to expand the institutional capacity of the council. The United States resisted this expansion until it was sure a secretariat would not threaten state autonomy or stifle the council's effectiveness. States constructed the secretariat and the PSI to protect state autonomy. The secretariat that emerged is weak, in keeping with the preferences of the United States. The form of negotiation was important in the evolution of the council's institutional capacity. Norway cleverly established a temporary secretariat. 
The United States, Canada, and Russia could not veto that proposal. The utility of this secretariat led to the creation of a permanent secretariat, as per a neo-liberal hypothesis of institutional evolution.

Returning to the literature, a new understanding of the evolution of the council's institutional capacity is necessary. In contrast to earlier work by authors such as Oran Young, ${ }^{118}$ the council is a stronger institution than ever before. Belen Sanchez Ramos provides insight arguing that new "challenges and opportunities" in the Arctic as well as increasing "complexity" are partly the cause of the expansion of the council's institutional capacity, as seen in the increase in the volume of council projects. ${ }^{119}$ The council secretariat arose partly due to the council's more complex mandate. In addition, the council's secretariat and project support instrument did not arise automatically. Rather, resistant countries only agreed to a stronger institutional capacity when it became clear they could control the institution. In addition, the Nordic policy-makers desired increased institutional capacity in order to have a means to control Russia and increase the credibility of the council. This article contributes a new understanding of the evolution of the council's institutional capacity. The way that negotiations proceeded was important; some states had to come around to the idea that an increased capacity would benefit their work in the council.

Scholars who advocate for the council to carry out more work than it does now would be wise to address the deficiencies in the institutional capacity of the council. ${ }^{120}$ The council lacks the capacity either to compel states to undertake any action or to enforce international agreements. Currently, the secretariat has fewer than one dozen employees. States have deliberately structured the council secretariat and PSI to ensure it will remain a weak institution that states can control. It is important to consider what projects the council can add to its workload given the current political situation.

\section{Author}

Andrew Chater is an assistant professor (limited term) of humanities at Brescia University College in London, Ontario; a fellow at the Polar Research and Policy Initiative; and the 2018-2019 Canada Fulbright Visiting Chair in Arctic Studies at the University of Washington. 


\section{Notes}

1. Sakiko Fakuda-Parr, Carlos Lopes, and Khalid Malik, "Institutional Innovations for Capacity Development," in Capacity for Development: New Solutions to Old Problems, eds. Sakiko Fakuda-Parr, Carlos Lopes, and Khalid Malik (New York: Earthscan Publications/United Nations Development Programme, 2002), 8.

2. Oran Young, "Governing the Arctic: From Cold War Theater to Mosaic of Co-operation," Global Governance 11, no. 1 (2005): 11.

3. Rob Huebert, "New Directions in Circumpolar Co-operation: Canada, the Arctic Environmental Protection Strategy and the Arctic Council," Canadian Foreign Policy 5, no. 2 (1998): 54.

4. Timo Koivurova and David L. Vanderzwaag, "The Arctic Council at 10 Years: Retrospect and Prospects," UBC Law Review 40, no. 1 (2006): 191; Timo Koivurova, "Limits and Possibilities of the Arctic Council in a Rapidly Changing Scene of Arctic Governance," Polar Record 46, no. 2 (2010): 147.

5. Olav Schram Stokke, "A Legal Regime for the Arctic?: Interplay with the Law of the Sea Convention," Marine Policy 31, no. 4 (2007): 407-408.

6. Evan T.Bloom, "Establishment of the Arctic Council," The American Journal of International Law 93, no. 3 (1999): 718-719.

7. Terry Fenge, "Canada and the Arctic Council: Our Turn to Conduct the Arctic Orchestra," Policy Options, April 2012, 64.

8. Belén Sánchez Ramos, "Strengthening the Capacity of the Arctic Council: Is the Permanent Secretariat a First Step," in Arctic Yearbook 2013, ed. Lassi Heininen (Akureyri, Iceland: Northern Research Forum, 2013), 266.

9. Ramos, "Strengthening the Capacity," 272.

10. For example, Bastiaan van Apeldoorn, Henk Overbeek, and Magnus Ryner, "Theories of European Integration: A Critique," in A Ruined Fortress?: Neoliberal Hegemony and Transformation in Europe, eds. Alan W. Cafruny and Magnus Ryner (Oxford: Rowan and Littlefield, 2003), 21.

11. For example, Robert O. Keohane and Lisa L. Martin, "The Promise of Institutionalist Theory: Response to John Mearsheimer," International Security 20, no. 1 (1995): 42; Robert Axelrod and Robert O. Keohane, "Achieving Co-operation under Anarchy: Strategies and Institutions," World Politics 38, no. 1 (1985): 238-239.

12. See The Munk-Gordon Arctic Security Program, Canada as an Arctic Power: Preparing for the Canadian Chairmanship of the Arctic Council 20132015 (Toronto, Ontario: Munk School of Global Affairs and the Walter and Duncan Gordon Foundation, 2012); Michael Byers, Circumpolar Challenges: An Ambitious Agenda for the Arctic Council (Ottawa, Ontario: Rideau Institute, 2012); Andrea Charron, "Canada and the Arctic Council," 
International Journal 67, no. 3 (2012): 775-783; Alison Ronson, "Political Climate Change: The Evolving Role of the Arctic Council," Northern Review 33 (2011): 95-111.

13. See Byers, Circumpolar Challenges.

14. Oded Cedar, "The Arctic Council: Gatekeeper or Doormat to the World's Next Major Resource Battle," Sustainable Development Law and Policy 12, no. 1 (2011): 40.

15. Former United States delegation member and environment official, spring 2013.

16. John English, Ice and Water: Politics, Peoples and the Arctic Council (Toronto, Ontario: Allen Lane, 2013), 139.

17. The Arctic Monitoring and Assessment Programme, PCB in the Russian Federation: Inventory and Proposals for Priority Remedial Actions (Oslo, Norway: Arctic Council, 2000), 6.

18. For example, see English, Ice and Water, 139.

19. Arctic Council, Arctic Human Development Report (Tromsø, Norway: Arctic Council Secretariat, 2004), 158. According to the report, life expectancy among Russian Indigenous peoples declined 4.8 years from 1990 until 1995. This decline occurred because of high alcohol consumption, poor economic performance, and high levels of stress.

20. Former United States delegation member and environment department official, spring 2013.

21. English, Ice and Water, 202.

22. For examples and details of disagreements, see English, Ice and Water, 127.

23. English, Ice and Water, 228.

24. Interview with former Canadian delegation member and foreign affairs official, as well as a former United States delegation member and State Department official, winter and spring 2013.

25. Thomas S. Axworthy and Ryan Dean, "Changing the Arctic Paradigm from Cold War to Cooperation: How Canada's Indigenous Leaders Shaped the Arctic Council," Yearbook of Polar Law 7 (2013): 30.

26. Gordon Barthos, "Canada to Steer New Body on Protecting the Arctic," Toronto Star, January 20, 1996.

27. Interview with former delegation member and Yukon government employee, winter 2013.

28. For example, four former Canadian delegation members made this claim during interviews in winter 2013, including a senior Canadian foreign affairs official, a junior Canadian foreign affairs official, a senior United States State Department official, and a junior United States State Department official. 
Canadian officials also emphasized that Canada was leery of burdens resulting from contributions.

29. Christopher Cuddy, contributor to the PAME and former Canadian delegation member, February 21, 2013.

30. Cuddy, February 21, 2013.

31. Ray Arnaudo, former United States delegation member and council chair, April 17, 2013

32. Adele Dion, former Canadian Senior Arctic Official, March 13, 2013.

33. Former Icelandic delegation member and current foreign affairs official, spring 2013.

34. Former United States delegation member and environment department official, spring 2013.

35. Former United States delegation member and environment department official, spring 2013.

36. Former high-ranking United States negotiator, State Department official and delegation member, spring 2013.

37. Arctic Council, Rules of Procedure (Iqaluit, Nunavut: Arctic Council Ministerial Meeting, 1998), Article 29.

38. Arctic Council, Rules of Procedure, Article 33.

39. Arctic Council, Rules of Procedure., Article 32.

40. Arctic Council, Senior Arctic Officials Meeting, Anchorage, Alaska, U.S.A., May 5-6, 1999 (Tromsø, Norway: Arctic Council Secretariat, 1999).

41. Arctic Council, The Barrow Declaration (Barrow, Alaska: Arctic Council Ministerial Meeting, 2000).

42. Arctic Council, Senior Arctic Officials Meeting, Anchorage, Alaska, U.S.A., May 5-6, 1999.

43. Arctic Council, Senior Arctic Officials Meeting, May 1999.

44. Arctic Council, The Inari Declaration (Inari, Finland: Arctic Council Ministerial Meeting, 2002).

45. Arctic Council, Senior Arctic Officials Meeting, Anchorage, Alaska, U.S.A., May 5-6, 1999.

46. Arctic Council, Senior Arctic Officials, May 1999.

47. Arctic Council, Senior Arctic Officials, May 1999.

48. Arctic Council, Senior Arctic Officials, May 1999.

49. Arctic Council, Senior Arctic Officials, May 1999.

50. Arctic Council, Notes from the Second Ministerial Meeting, Barrow, Alaska, U.S.A., October 12-13, 2000 (Tromsø, Norway: Arctic Council Secretariat, 2000).

51. Arctic Council, Notes from the Second Ministerial Meeting, 2000.

52. Arctic Council, Notes from the Second Ministerial Meeting, 2000. 
53. Arctic Council, The Barrow Declaration.

54. Arctic Council, Arctic Council Senior Arctic Officials' Meeting, Rovaniemi, Finland, June 12-13, 2001 (Tromsø, Norway: Arctic Council Secretariat, 2001).

55. Arctic Council, Senior Arctic Officials' Meeting, 2001.

56. Arctic Council, Senior Arctic Officials' Meeting, 2001.

57. Arctic Council, Senior Arctic Officials' Meeting, 2001.

58. Pekka Haavisto, Review of the Arctic Council Structures (Tromsø, Norway: Arctic Council, 2001).

59. Arctic Council, The Inari Declaration.

60. Arctic Council, Arctic Council Meeting of Senior Arctic Officials, Reykjavik, Iceland, April 9-10, 2003: Minutes (Tromsø, Norway: Arctic Council Secretariat, 2003).

61. Arctic Council, Meeting of Senior Arctic Officials, April 2003

62. Arctic Council, Arctic Council Meeting of Senior Arctic Officials, Svartsengi,, Iceland, 23-24 October, 2003 (Tromsø, Norway: Arctic Council, 2003).

63. Arctic Council, Meeting of Senior Arctic Officials, October 2003.

64. Arctic Council, Meeting of Senior Arctic Officials, October 2003.

65. Arctic Council, Meeting of Senior Arctic Officials, October 2003.

66. Arctic Council, Meeting of Senior Arctic Officials, October 2003.

67. Arctic Council, Arctic Council Meeting of Senior Arctic Officials, Reykjavik, Iceland, November 22-23, 2004, Draft Minutes (Tromsø, Norway: Arctic Council, 2004).

68. Arctic Council, Meeting of Senior Arctic Officials, November 2004.

69. Arctic Council, Meeting of Senior Arctic Officials, November 2004.

70. Arctic Council, Meeting of Senior Arctic Officials, November 2004.

71. Arctic Council, Meeting of Senior Arctic Officials, November 2004.

72. Arctic Council, Arctic Council Meeting of Senior Arctic Officials, Yakutsk, Russia, April 6-7, 2005: Minutes (Tromsø, Norway: Arctic Council Secretariat, 2005).

73. Arctic Council, Meeting of Senior Arctic Officials, April 2005.

74. Arctic Council, Meeting of Senior Arctic Officials, April 2005.

75. Arctic Council, Meeting of Senior Arctic Officials, April 2005.

76. Arctic Council, The Salekhard Declaration (Tromsø, Norway: Arctic Council 2006).

77. Arctic Council, The Salekhard Declaration.

78. Arctic Council, Arctic Council Meeting of Senior Arctic Officials, Tromse, Norway, 12-13 April 2007 (Tromsø, Norway: Arctic Council Secretariat, 2001). 
79. Arctic Council, Deputy Ministers Meeting, May 2012 (Tromsø, Norway: Arctic Council. 2012).

80. Former Icelandic delegation member and current foreign affairs official, spring 2013.

81. Former Icelandic delegation member and current foreign affairs official, spring 2013.

82. Former Icelandic delegation member and current foreign affairs official, spring 2013.

83. Former Icelandic delegation member and current foreign affairs official, spring 2013.

84. Former Icelandic delegation member and current foreign affairs official, spring 2013.

85. Former Icelandic delegation member and current foreign affairs official, spring 2013.

86. Former Icelandic delegation member and current foreign affairs official, spring 2013.

87. Former Icelandic delegation member and current foreign affairs department official, spring 2013.

88. Mia Bennett, "Arctic Council Finds Permanent Housing in Tromsø, Norway," Alaska Dispatch, June 12, 2013, accessed July 2, 2013, http://www.alaskadispatch.com/article/20130612/ arctic-council-finds-permanent-housing-troms-norway.

89. Former Icelandic delegation member and current foreign affairs department official, spring 2013.

90. Adele Dion, former Canadian Senior Arctic Official, March 13, 2013. The reasoning behind Norway's stand was reiterated in an interview with a former United States delegation member, spring 2013.

91. Interview with former Canadian delegation member and Yukon government employee, winter 2013.

92. Interview with former Canadian delegation member and Yukon government employee, winter 2013.

93. Ray Arnaudo, former United States delegation member and Council chair, April 17, 2013.

94. Ray Arnaudo, April 2013.

95. Arctic Council, Meeting of Senior Arctic Officials Final Report, 28-29 November 2007, Narvik, Norway (Tromsø, Norway: Arctic Council, 2007) and Arctic Council, Meeting of Senior Arctic Officials Final Report, 23-24 April 2008, Svolver, Norway (Tromsø, Norway: Arctic Council, 2008).

96. Arctic Council, Meeting of Senior Arctic Officials Final Report, 23-24 April 2008, Svolver, Norway. 
97. Arctic Council, Meeting of Senior Arctic Officials Final Report, 19-20 November 2008, Kautokeino, Norway (Tromsø, Norway: Arctic Council, 2008).

98. Arctic Council, Meeting of Senior Arctic Officials, November 2008

99. Arctic Council, Meeting of Senior Arctic Officials Final Report, 12-13 November 2009, Copenhagen (Tromsø: Arctic Council Secretariat, 2009).

100. Arctic Council, Meeting of Senior Arctic Officials, Lulea, 8-9 November 2011, Final Report (Tromsø, Norway: Arctic Council, 2011).

101. Arctic Council, Meeting of Senior Arctic Officials, November 2011,

102. Arctic Council, "Arctic Pollution Prevention and Mitigation Fund Becomes Operational," Arctic Council Nerws, March 13, 2014, accessed June 16, 2014, http://www.arctic-council.org/index.php/en/resources/news-and-press/ news-archive/851-arctic-pollution-prevention-and-mitigation-fundbecomes-operational.

103. Arctic Council, "Arctic Pollution Prevention."

104. NEFCO, "New Agreements Pave the Way for Environmental Cooperation in the Arctic," NEFCO News, March 3, 2014, accessed June 16, 2014, http://www.nefco.org/news/new_agreements_pave_the_way_for_ environmental_co_operation_in_the_arctic.

105. NEFCO, "New Agreements."

106. NEFCO, "New Agreements."

107. Former Canadian delegation member and current Foreign Affairs official, winter 2013. Norway contributes more as a secretariat host. The total budget is $\$ 1.7$ million annually.

108. Interview with former Canadian delegation member and foreign affairs official, winter 2013.

109. Arctic Council, Arctic Council Rules of Procedure (Tromsø, Norway: Arctic Council, 2011), section 12.

110. Arctic Council, Rules of Procedure, section 16.

111. Arctic Council, Rules of Procedure, 19.

112. Arctic Council, Rules of Procedure, 45.

113. Arctic Council, Rules of Procedure, 46.

114. Arctic Council, Rules of Procedure, 10.

115. Arctic Council, Rules of Procedure, 21.

116. Arctic Council, "The Arctic Council Secretariat," November 4, 2016, https://www.arctic-council.org/index.php/en/about-us/arctic-council/ the-arctic-council-secretariat.

117. Arctic Council, "The Arctic Council Secretariat."

118. Oran Young, "Governing the Arctic,"13-14.

119. Ramos, "Strengthening the Capacity of the Arctic Council," 264-279. 
120. See The Munk-Gordon Arctic Security Program, Canada as an Arctic Power: Preparing for the Canadian Chairmanship of the Arctic Council 2013-2015; Michael Byers, Circumpolar Challenges: An Ambitious Agenda for the Arctic Council; Andrea Charron, "Canada and the Arctic Council," 775-783; Alison Ronson, "Political Climate Change: The Evolving Role of the Arctic Council," 95-111.

\section{Bibliography}

Apeldoorn, Bastiaan van, Henk Overbeek, and Magnus Ryner. "Theories of European Integration: A Critique."In A Ruined Fortress?: Neoliberal Hegemony and Transformation in Europe, edited by Alan W. Cafruny and Magnus Ryner, 17-46. Oxford: Rowan and Littlefield, 2003.

Axelrod, Robert and Robert O. Keohane. "Achieving Co-operation under Anarchy: Strategies and Institutions." World Politics 38, no. 1 (1985): 226-254.

Axworthy, Thomas S. and Ryan Dean, "Changing the Arctic Paradigm from Cold War to Cooperation: How Canada's Indigenous Leaders Shaped the Arctic Council." Yearbook of Polar Law 7 (2013): 7-43.

Barthos, Gordon. "Canada to Steer New Body on Protecting the Arctic." Toronto Star, January 20, 1996.

Bennett,Mia."Arctic CouncilFinds Permanent Housing in Tromsø,Norway." Alaska Dispatch,June 12,2013.AccessedJuly 2,2013. http://www.alaskadispatch.com/ article/20130612/arctic-council-finds-permanent-housing-troms-norway.

Bloom, Evan T. "Establishment of the Arctic Council." The American Journal of International Law 93, no. 3 (1999): 712-722.

Byers, Michael. Circumpolar Challenges: An Ambitious Agenda for the Arctic Council. Ottawa, Ontario: Rideau Institute, 2012.

Cedar, Oded. "The Arctic Council: Gatekeeper or Doormat to the World's Next Major Resource Battle?” Sustainable Development Law and Policy 12, no. 1 (2011): 40, 51, 61, 67.

Charron, Andrea. "Canada and the Arctic Council." International Journal 67, no. 3 (2012): 775-783.

English, John. Ice and Water: Politics, Peoples and the Arctic Council. Toronto, Ontario: Allen Lane, 2013.

Fakuda-Parr, Sakiko, Carlos Lopes, and Khalid Malik. "Institutional Innovations for Capacity Development.” In Capacity for Development: New Solutions to Old Problems, edited by Sakiko Fakuda-Parr, Carlos Lopes, and Khalid Malik, 1-21. New York: Earthscan Publications/United Nations Development Programme, 2002. 
Fenge, Terry. "Canada and the Arctic Council: Our Turn to Conduct the Arctic Orchestra." Policy Options, April 2012, 63-67.

Huebert, Rob. "New Directions in Circumpolar Co-operation: Canada, the Arctic Environmental Protection Strategy and the Arctic Council." Canadian Foreign Policy 5, no. 2 (1998): 37-57.

Keohane, Robert O., and Lisa L. Martin. "The Promise of Institutionalist Theory: Response to John Mearsheimer." International Security 20, no. 1 (1995): 39-51.

Koivurova, Timo, and David L. Vanderzwaag. "The Arctic Council at 10 Years: Retrospect and Prospects." UBC Law Review 40, no. 1 (2006): 121-194.

Koivurova, Timo. "Limits and Possibilities of the Arctic Council in a Rapidly Changing Scene of Arctic Governance.” Polar Record 46, no. 2 (2010): 145-156.

Munk-Gordon Arctic Security Program. Canada as an Arctic Power: Preparing for the Canadian Chairmanship of the Arctic Council 2013-2015. Toronto, Ontario: Munk School of Global Affairs and the Walter and Duncan Gordon Foundation, 2012.

Ramos, Belén Sánchez. "Strengthening the Capacity of the Arctic Council: Is the Permanent Secretariat a First Step.” In Arctic Yearbook 2013, edited by Lassi Heininen, 264-279. Akureyri, Iceland: Northern Research Forum, 2013.

Ronson, Alison. "Political Climate Change: The Evolving Role of the Arctic Council." Northern Review 33 (2011): 95-111.

Stokke, Olav Schram. "A Legal Regime for the Arctic?: Interplay with the Law of the Sea Convention." Marine Policy 31, no. 4 (2007): 402-408.

Young, Oran. "Governing the Arctic: From Cold War Theater to Mosaic of Cooperation." Global Governance 11, no. 1 (2005): 9-15.

Primary Documents

The Arctic Monitoring and Assessment Programme. PCB in the Russian Federation: Inventory and Proposals for Priority Remedial Actions. Oslo, Norway: Arctic Council, 2000.

Arctic Council. Arctic Council Meeting of Senior Arctic Officials, Reykjavik, Iceland, April 9-10, 2003: Minutes. Tromsø, Norway: Arctic Council Secretariat, 2003.

Arctic Council. Arctic Council Meeting of Senior Arctic Officials, Reykjavik, Iceland, November 22-23, 2004. Tromsø, Norway: Arctic Council Secretariat, 2004.

Arctic Council. Arctic Council Meeting of Senior Arctic Officials, Svartsengi, Iceland, 23-24 October, 2003. Tromsø, Norway: Arctic Council, 2003.

Arctic Council. Arctic Council Meeting of Senior Arctic Officials, Tromsø, Norway, 12-13 April 2007. Tromsø, Norway: Arctic Council Secretariat, 2007. 
Arctic Council. Arctic Council Meeting of Senior Arctic Officials, Yakutsk, Russia, April 6-7, 2005: Minutes. Tromsø, Norway: Arctic Council Secretariat, 2005.

Arctic Council. Arctic Council Senior Arctic Officials' Meeting, Rovaniemi, Finland, June 12-13, 2001. Tromsø, Norway: Arctic Council Secretariat, 2001.

Arctic Council. Arctic Council Rules of Procedure. Tromsø, Norway: Arctic Council, 2011.

Arctic Counci. "The Arctic Council Secretariat." November 4, 2016. https://www.arctic-council.org/index.php/en/about-us/arctic-council/ the-arctic-council-secretariat.

Arctic Council. Arctic Human Development Report. Tromsø, Norway: Arctic Council Secretariat, 2004.

Arctic Council. "Arctic Pollution Prevention and Mitigation Fund Becomes Operational.” Arctic Council News, March 13, 2014. Accessed June 16, 2014. http://www.arctic-council.org/index.php/en/resources/news-andpress/news-archive/851-arctic-pollution-prevention-and-mitigation-fundbecomes-operational.

Arctic Council. Barrow Declaration. Barrow, Alaska: Arctic Council Ministerial Meeting, 2000.

Arctic Council. Deputy Ministers Meeting, May 2012. Tromsø, Norway: Arctic Council. 2012.

Arctic Council. The Inari Declaration. Tromsø, Norway: Arctic Council Secretariat, 2002.

Arctic Council. Meeting of Senior Arctic Officials Final Report, 12-13 November 2009, Copenhagen. Tromsø: Arctic Council Secretariat, 2009.

Arctic Council. Meeting of Senior Arctic Officials Final Report, 19-20 November 2008, Kautokeino, Norway. Tromsø, Norway: Arctic Council, 2008.

Arctic Council. Meeting of Senior Arctic Officials, Lulea, 8-9 November 2011, Final Report. Tromsø, Norway: Arctic Council, 2011.

Arctic Council. Meeting of Senior Arctic Officials Final Report, 28-29 November 2007, Narvik, Norway. Tromsø, Norway: Arctic Council, 2007.

Arctic Council. Meeting of Senior Arctic Officials Final Report, 23-24 April 2008, Svolver, Norway. Tromsø, Norway: Arctic Council, 2008.

Arctic Council. Notes from the Second Ministerial Meeting, Barrow, Alaska, U.S.A., October 12-13, 2000. Tromsø, Norway: Arctic Council Secretariat, 2000.

Arctic Council. Participant List, Arctic Council's SAO Meeting, 12-13 June 2001, Rovaniemi, Finland. Rovaniemi, Finland: Arctic Council Secretariat, 2000.

Arctic Council. Rules of Procedure. Iqaluit, Nunavut: Arctic Council Ministerial Meeting, 1998. 
Arctic Council. The Salekbard Declaration. Tromsø, Norway: Arctic Council 2006.

Arctic Council. Senior Arctic Officials Meeting, Anchorage, Alaska, U.S.A., May 5-6, 1999. Tromsø, Norway: Arctic Council Secretariat, 1999.

Haavisto, Pekka. Review of the Arctic Council Structures. Tromsø, Norway: Arctic Council, 2001.

The Nordic Environmental Finance Corporation. "New agreements pave the way for environmental co-operation in the Arctic." NEFCO Nerws, March 3, 2014. Accessed June 16, 2014. http://www.nefco.org/news/new agreements pave the way for environmental co operation in the arctic. 